\title{
EFEKTIVITAS PROGRAM KELUARGA HARAPAN (PKH) DI DESA SUMBER KEJAYAN KECAMATAN MAYANG KABUPATEN JEMBER
}

\author{
Nurul Infitah ${ }^{1}$, Sukidin ${ }^{1}$, Wiwin Hartanto ${ }^{1}$ \\ ${ }^{1}$ Program Studi Pendidikan Ekonomi , Fakultas Keguruan dan Ilmu Pendidikan, Universitas Jember \\ e-mail: nurulinfitah@gmail.com
}

\begin{abstract}
Abstrak
Penelitian ini merupakan penelitian evaluasi yang bertujuan untuk mengetahui efektivitas PKH pada aspek input, proses dan output di Desa Sumber Kejayan Kecamatan Mayang Kabupaten Jember. Subjek penelitian ini adalah Keluarga Penerima Manfaat (KPM) di Desa Sumber Kejayan yang terdiri dari 84 responden. Metode pengumpulan data yang digunakan adalah kuesioner, dokumen dan observasi de ngan teknik analisis data persentase. Hasil penelitian menunjukkan bahwa PKH di Desa Sumber Kejayan Kecamatan Mayang Kabupaten Jember telah efektif pada aspek input, proses dan output bidang pendidikan dan kesejahteraan sosial. Persentase hasil penelitian pada aspek input menunjukkan hasil sebesar $68,3 \%$, aspek proses sebesar $84 \%$ dan output bidang pendidikan untuk kriteria anak usia sekolah didaftarkan di satuan pendidikan sebesar $99 \%$ dan persentase kehadiran anak usia sekolah sebesar $88 \%$ serta kesejahteraan sosial sebesar $84 \%$. Sedangkan pada aspek output bidang kesehatan pada kategori KPM usia 1-5 tahun belum efektif. Hal itu dikarenakan dari 8 (delapan) kriteria terdapat 2 (dua) kriteria responden yang memiliki anak usia 0-11 bulan yang tidak sesuai dengan persentase yang diharapkan. Kriteria tersebut adalah frekuensi Ibu yang kurang dalam memeriksakan kesehatan ke fasilitas kesehatan pada masa nifas sebesar $44 \%$ dan kriteria tentang frekuensi yang kurang pada pemeriksaan kesehatan bayi 0-1 bulan di fasilitas kesehatan sebesar 32\%. Kemudian indikator output PKH yang belum efektif juga terdapat pada pola makan anak usia 1-5 tahun dalam kesehariannya yang belum memenuhi 4 (empat) sehat 5 (lima) sempurna yaitu sebesar $40 \%$.
\end{abstract}

Kata Kunci: Program Keluarga Harapan, Efektivitas input, proses dan output.

\section{PENDAHULUAN}

Permasalahan kemiskinan merupakan masalah yang kompleks, yang memerlukan perhatian khusus, salah satu permasalahan sosial yang diakibatkan dari kemiskinan adalah rendahnya tingkat pendidikan. Kemiskinan dapat menyebabkan bertambahnya jumlah anak yang putus sekolah yang bersumber dari Keluarga Miskin (KM) dan dapat berpengaruh pada kondisi kesehatan masyarakat yaitu rentannya terkena penyakit dan resiko kekurangan gizi bagi ibu hamil, sehingga akan mempengaruhi kondisi kesehatan janin (Indrayani, 2014:2). Data BPS menurut hasil Susenas Tahun 2016-2018 bahwa persentase Ibu di daerah perkotaan dan pedesaan yang mempunyai keluhan kesehatan dalam sebulan terakhir menurut provinsi di Jawa Timur Tahun 2018 adalah sebesar $33.80 \%$. Tingkat kesejahteraan masyarakat, juga terlihat dari angka kematian bayi dan angka harapan hidup (Sjafari, 2014: 49).

Kabupaten Jember adalah salah satu kabupaten sebagai penerima PKH di Provinsi Jawa Timur dengan data kemiskinan sebesar 243.42 ribu orang. Menurut Badan Pusat Statistik, Rumah tangga miskin Kabupaten Jember Tahun 2017 sebanyak 178.346. Jika melihat data di BPS tahun 2017 Kabupaten Jember tersebut, memiliki tingkat kemiskinan yang tergolong tinggi, padahal Kabupaten Jember memiliki pertumbuhan ekonomi sebesar 5,21\% pada Tahun 2016, selain itu juga terdapat Kantor Perwakilan Bank Indonesia di Jember. Garis kemiskinan Kabupaten Jember Tahun 2018 sebesar $324.174 \mathrm{Rp} / \mathrm{Kap} /$ bulan. Garis kemiskinan adalah harga yang harus dibayar oleh kelompok acuan untuk memenuhi kebutuhan pangan sebesar $2100 \mathrm{kkal} / \mathrm{kapita} / \mathrm{hari}$ dan kebutuhan pangan yang esensial seperti sandang dan papan.

Tingkat keluarga prasejahtera di suatu daerah juga menentukan dalam pemberian bantuan sosial bersyarat. Berdasarkan data BPS Kabupaten Jember, data keluarga prasejahtera di Kecamatan Mayang tahun 2017 sebanyak 3.550 dari total populasi sebanyak 17.019 yang terdiri dari 7 (tujuh) Desa. Jumlah tersebut tidak mengalami penurunan selama tiga tahun terakhir yaitu semenjak tahun 2015. Padahal kecamatan tersebut merupakan penerima bantuan sosial bersyarat dari Program 
Keluarga Harapan (PKH). Harapan program tersebut adalah menurunkan tingkat kemiskinan di daerah-daerah yang memiliki tingkat kemiskinan yang tinggi.

Mengingat keluarga prasejahtera di Kecamatan Mayang, khususnya di Desa Sumber Kejayan masih tergolong tinggi, maka perlu adanya salah satu upaya penanggulangan yang dilakukan untuk mengurangi jumlah kemiskinan di Kabupaten Jember. Penanggulangan kemiskinan tersebut adalah PKH. Sumber Kejayan adalah salah satu desa di Kabupaten Jember yang telah melaksanakan PKH dengan data keluarga prasejahtera sebanyak 671 keluarga tahun 2017, dimana data keluarga prasejatera di desa tersebut merupakan desa tertinggi di antara 7 (tujuh) desa di Kecamatan Mayang yang tergolong keluarga prasejahtera. Oleh karena itu dari latar belakang permasalahan tersebut, Peneliti bermaksud untuk melaksanakan penelitian yang berjudul "Efektivitas Program Keluarga Harapan (PKH) di Desa Sumber Kejayan Kecamatan Mayang Kabupaten Jember" sehingga penelitian ini dapat dijadikan sumber informasi dan bahan evaluasi dalam penyaluran bantuan sosial PKH.

Jones dalam bukunya yang berjudul Organizational Theory: Text and Cases mengatakan bahwa efektivitas organisasi dapat dilihat dari 3 (tiga) tahap yaitu input, proses dan output (Jones, 1993:349). Kemudian menurut Tulus (1996 dalam Indrayani 2014:4) mengatakan bahwa efektivitas program dapat dilihat dari kepuasan pelanggan dalam mengikuti sebuah program. Hal serupa juga dikatakan oleh Budiani (2007:53) bahwa efektivitas suatu program terdiri dari ketepatan sasaran, tujuan program, sosialisasi program dan pemantauan program. Indikator yang masuk dalam proses PKH adalah tujuan program, sosialisasi program, dan pemantauan program yang dilakukan oleh pendamping PKH. Kemudian untuk indikator ketepatan sasaran masuk pada kategori input. Sehingga dapat disimpulkan bahwa teori tentang efektivitas program semuanya meliputi indikator

\section{METODE}

Pendekatan yang digunakan oleh Peneliti dalam penelitian ini adalah pendekatan evaluasi. Pendekatan yang menggunakan analisis persentase untuk mengevaluasi efektivitas PKH. Penentuan responden penelitian menggunakan jenis probability sampling dengan teknik proportionate stratified random sampling. Variabel yang digunakan dalam penelitian ini adalah variabel tunggal atau mandiri yaitu efektivitas PKH. Adapun populasi di Desa tersebut sebanyak 503 KPM dengan kategori pendidikan sebanyak 339 KPM, kesehatan sebanyak 104 KPM dan kesejahteraan sebanyak 60 KPM. Berdasarkan Rumus Slovin sampel penelitian ini adalah 84 responden dengan kategori pendidikan sebanyak 56 sampel, kesehatan 18 sampel dan kesejahteraan sosial 10 sampel. Teknis analisis data mengunakan persentase berdasarkan dari Budiani (2007:53) sebagai berikut:

$$
\text { Persentase Input }=\frac{\text { Realisasi }}{\text { Target }} \times 100
$$

Skoring pada setiap item pertanyaan kuesioner pada indikator proses penelitian ini menggunakan skala likert, seperti pada tabel berikut:

Tabel 1. Skoring Instrumen Penelitian

\begin{tabular}{clc}
\hline Opsi & Alternatif Jawaban & Bobot Nilai \\
\hline a & Sangat Tidak Setuju & 1 \\
\hline b & Tidak Setuju & 2 \\
\hline c & Setuju & 3 \\
\hline d & Sangat Setuju & 4
\end{tabular}

Sumber: Neolaka, 2016

Kemudian pada indikator input dan output, menggunakan rating scale. Misalnya pada item pertanyaan tentang status kepemilikan rumah tempat tinggal yaitu opsi status kepemilikan rumah milik orang lain mendapat skor 4, tanah milik negara mendapat skor 3, tanah milik bersama dengan keluarga mendapat skor 2, dan tanah milik sendiri mendapat skor 1. 


\section{HASIL DAN PEMBAHASAN Hasil Penelitian}

Berdasarkan hasil penelitian tentang Efektivitas Program Keluarga Harapan (PKH) di Desa Sumber Kejayan Kecamatan Mayang Kabupaten Jember diperoleh hasil sebagai berikut:

1. Input

Indikator input melihat ketepatan sasaran Keluarga Penerima Manfaat (KPM) berdasarkan 14 (empat belas) kriteria sebagai Keluarga Miskin (KM) dalam Basis Data Terpadu yang ditetapkan oleh Kementerian Sosial melalui Tim Nasional Program Penanggulangan Kemiskinan (TNP2K). Kriteria tersebut di antaranya adalah 1) Status kepemilikan bangunan tempat tinggal 2) Status lahan tempat tinggal yang ditempati 3) Jenis lantai terluas 4) Jenis dinding terluas 5) Kondisi dinding 6) Jenis atap terluas 7) Kondisi atap 8) Sumber air minum 9) Cara membeli air minum 10) Sumber penerangan 11) Daya Penerangan 12) Bahan bakar utama untuk memasak 13) Kepemilikan fasilitas BAB 14) Jenis Kloset. Berdasarkan hasil penelitian yang dilakukan di Desa Sumber Kejayan Kecamatan Mayang Kabupaten Jember diperoleh hasil pada indikator input sebesar 68,49\%. Persentase ini menunjukkan hasil yang efektif menurut Pedoman Pemutakhiran Mandiri Data Terpadu Program Penanganan Fakir Miskin Tahun 2016, karena melebihi dari persentase 64\% yang ditetapkan Kementerian Sosial.

\section{Proses}

Berdasarkan Peraturan Menteri No 10 Tahun 2018 indikator proses PKH terdapat 5 (lima) kriteria yaitu 1) Pertemuan awal dan validasi 2) Pertemuan kelompok bulanan 3) Verifikasi komitmen 4) Penyaluran bantuan 5) Pemutakhiran data. Berdasarkan hasil penelitian yang dilakukan di Desa Sumber Kejayan Kecamatan Mayang Kabupaten Jember diperoleh persentase sebesar $84 \%$. Persentase tersebut kemudian diinterpretasikan pada acuan efektivitas menurut Litbang Depdagri tahun 1991 sebagai berikut:

Tabel 2. Predikat efektivitas

\begin{tabular}{ll}
\hline Rasio Efektivitas & \multicolumn{1}{c}{ Tingkat Capaian } \\
\hline Dibawah 40\% & Sangat tidak efektif \\
$40-59,99 \%$ & Tidak Efektif \\
$60-79,99 \%$ & Cukup Efektif \\
Diatas $80 \%$ & Sangat Efektif \\
\hline
\end{tabular}

Berdasarkan tabel predikat efektivitas di atas, maka indikator proses PKH berada pada kategori sangat efektif yaitu di atas $80 \%$.

\section{Output}

Peraturan Menteri No 10 Tahun 2018 bahwa kategori penerima PKH terdiri dari kategori pendidikan, kesehatan dan kesejahteraan sosial. Efektivitas PKH pada indikatot output dapat diketahui dengan membandingkan antara persentase hasil penelitian dengan persentase yang diharapkan. Persentase yang diharapkan telah ditetapkan dalam pedoman PKH. Berikut hasil efektivitas PKH pada masing-masing kategori:

a. Kategori Pendidikan

Kategori pendidikan memiliki 2 (dua) kriteria yang dijabarkan dalam 2 (dua) item pertanyaan yang masuk dalam kuesioner penelitian. Pertanyaan tersebut diperuntukkan bagi KPM yang memiliki anak usia sekolah dari SD/sederajat sampai dengan SMA/Sederajat. Hasil penelitian menunjukkan bahwa, Pertama, item pertanyaan tentang anak usia sekolah yang mendaftarkan di satuan pendidikan SD/SMP/SMA adalah sebesar $99 \%$ dari 100\% target yang harus dicapai. Hasil ini menunjukkan bahwa masih terdapat KPM yang tidak mendaftarkan anaknya di satuan pendidikan. Alasan responden tidak mendaftarkan anaknya di satuan pendidikan, karena anak tersebut tidak kuat untuk melanjutkan sekolah secara kognitif. Artinya terdapat masalah di kemampuan anaknya untuk 
melanjutkan. Kedua, item pertanyaan tentang tingkat kehadiran anak usia sekolah. Berdasarkan penelitian yang dilakukan menunjukkan hasil sebesar $89 \%$ dari $85 \%$ kehadiran yang ditetapkan. Persentase ini menunjukkan bahwa anak usia sekolah telah memenuhi lebih dari persentase $85 \%$ kehadiran di sekolah.

b. Kategori Kesehatan

Kategori kesehatan terdapat 2 (dua) objek penerima PKH yaitu pada anak usia 0-11 bulan dan balita 1-5 tahun. Berikut penjelasan pada masing-masing objek penerima PKH kategori kesehatan:

\section{1) Kategori Kesehatan usia 0-11 bulan}

Penelitian yang dilakukan pada KPM memiliki anak usia 0-11 bulan tersebar menjadi 8 (delapan) item pertanyaan sesuai dengan kriteria yang telah ditetapkan Kementerian Sosial. Hasil penelitian dijabarkan sebagai berikut:

Tabel 3. Efektivitas output PKH bidang kesehatan kategori usia 0-11 bulan

\begin{tabular}{|c|c|c|c|}
\hline Indikator & $\begin{array}{l}\text { Persentase } \\
\text { Hasil } \\
\text { Penelitian }\end{array}$ & $\begin{array}{l}\text { Persentase } \\
\text { yang } \\
\text { diharapkan }\end{array}$ & Keterangan \\
\hline $\begin{array}{l}\text { Layanan antenatal care minimal } 4 \text { kali } \\
\text { selama masa kehamilan }\end{array}$ & $100 \%$ & $90 \%$ & Tercapai \\
\hline $\begin{array}{l}\text { Perolehan tablet } \mathrm{Fe} \\
\text { kehamilan }\end{array}$ & $95 \%$ & $100 \%$ & $\begin{array}{l}\text { Tidak } \\
\text { tercapai }\end{array}$ \\
\hline $\begin{array}{lccc}\text { Ibu } & \text { melahirkan } & \text { dibantu } & \text { tenaga } \\
\text { kesehatan terlatih } & & \\
\end{array}$ & $100 \%$ & $95 \%$ & Tercapai \\
\hline $\begin{array}{l}\text { Layanan postnatal care minimal } 3 \text { kali } \\
\text { selama nifas }\end{array}$ & $44 \%$ & $95 \%$ & $\begin{array}{l}\text { Tidak } \\
\text { tercapai }\end{array}$ \\
\hline $\begin{array}{l}\begin{array}{l}\text { Pemeriksaan bayi } \\
\text { minimal 3 kali }\end{array} \\
\end{array}$ & $32 \%$ & $100 \%$ & $\begin{array}{l}\text { Tidak } \\
\text { tercapai }\end{array}$ \\
\hline Vaksinasi lengkap balita 0-11 bulan & $100 \%$ & $95 \%$ & Tercapai \\
\hline $\begin{array}{l}\text { Kunjungan rutin setiap bulan bayi usia } \\
0-11 \text { bulan ke Posyandu }\end{array}$ & $95 \%$ & $95 \%$ & Tercapai \\
\hline $\begin{array}{l}\text { Perolehan tablet Vitamin A anak usia } 0- \\
11 \text { bulan sebanyak } 2 \text { kali pada Februari } \\
\text { dan Agustus }\end{array}$ & $95 \%$ & $95 \%$ & Tercapai \\
\hline $\begin{array}{l}\text { Monitoring berat badan anak usia } 1-5 \\
\text { tahun/kunjungan rutin setiap bulan ke } \\
\text { Posyandu }\end{array}$ & $80 \%$ & $80 \%$ & Tercapai \\
\hline
\end{tabular}

Sumber: Data diolah 2019

Berdasarkan item persentase efektivitas proses di atas, bahwa kriteria yang tidak tercapai adalah pertama, frekuensi ibu hamil mendapatkan suplemen Fe (zat besi) dari fasilitas kesehatan. Alasan responden saat hamil yang mendapatkan kurang dari 9 Fe (Zat besi), dikarenakan tidak ada tindak lanjut petugas kesehatan dalam pemberian suplemen, petugas tidak membagikan secara langsung di rumah masing-masing KPM, sehingga KPM diharuskan untuk mengambil ke fasilitas kesehatan. Alasan lain yang disampaikan responden adalah perihal waktu di pagi hari untuk mengambil sumplemen di fasilitas kesehatan. Responden mengaku kesulitan untuk mengambil di waktu tersebut, karena suami mereka harus pergi bekerja di waktu yang bersamaan, sehingga tidak ada yang mengantar untuk mengunjugi fasilitas kesehatan.

Kedua, kriteria tentang frekuensi pemeriksaan responden ke fasilitas kesehatan selama masa nifas. Adapun faktor yang melatarbelakangi responden tidak memeriksakan kesehatan pada saat nifas adalah karena merasa sehat, dan tidak perlu memeriksakan kesehatan ke fasilitas kesehatan. Pola pikir masyarakat yang tidak akan berkunjung ke puskesmas/bidan jika merasa kondisi masih sehat masih 
mendarahdaging di kalangan masyarakat Desa Sumber Kejayan, padahal saat masa nifas Ibu harus diberi postnatal care minimal 3 kali selama masa nifas. Kesadaran yang kurang pada Ibu saat nifas untuk memeriksakan kesehatannya di fasilitas kesehatan, juga menjadikan faktor ketidaktercapaian pada kriteria ini.

Ketiga, item pertanyaan tentang frekuensi pemeriksaan kesehatan di fasilitas kesehatan pada saat bayi berusia $0-1$ bulan. Alasan yang melatarbelakangi responden terhadap kurangnya frekuensi pemeriksaan bayi usia 0-1 bulan adalah kondisi bayi yang sehat dan tidak rewel, sehingga dari kondisi ini menyebabkan responden memeriksakan bayi 0-1 bulan kurang dari 3 kali, rata-rata jawaban responden adalah memeriksakan bayi hanya 1 kali. Kemudian sosialisasi yang kurang dari petugas fasilitas kesehatan tentang kewajiban KPM untuk memeriksakan kesehatan sebanyak 3x juga mempengaruhi dalam ketidaktercapaian kriteria ini. Sosialisasi tentang ciri-ciri bayi sehat dan sakit juga tidak ada yang dilakukan oleh fasilitas kesehatan, sehingga KPM merasa jika bayi tidak rewel, maka bayi mereka dapat dikatakan sehat dan tidak perlu dibawa ke fasilitas kesehatan.

2) Kategori Kesehatan balita 1-5 tahun

Hasil penelitian menunjukkan bahwa persentase yang dicapai dari kriteria tentang frekuensi Ibu membawa balita ke Posyandu untuk ditimbang adalah sebesar adalah sebesar 94\% dari $80 \%$ yang diharapkan. Persentase pada item ini adalah telah efektif karena telah melebihi target yang seharusnya dicapai. Kemudian kriteria item pertanyaan selanjutnya adalah pola makan balita setelah mendapat PKH yaitu sebesar 33\% dari target $80 \%$ telah menerapkan pola hidup sehat kepada anak balitanya dengan mengkonsumsi 4 sehat 5 sempurna, walaupun tidak rutin. Persentase ini belum tercapai dan belum efektif dalam implementasinya, karena persentase kurang dari persentase yang ditetapkan. Alasan responden belum menerapkan pola sehat dengan tidak memberikan makanan 4 sehat 5 sempurna, karena ingin hidup lebih hemat dan bantuan yang diberikan terkadang digunakan untuk berbagi untuk memenuhi kebutuhan sehari-hari dan untuk keperluan anak balitanya.

c. Bidang Kesejahteraan Sosial

Efektivitas output pada anak usia lanjut dapat dilihat dari dua indikator yaitu tentang frekuensi KPM mendapatkan makanan sehat dan perawatan kesehatan. Hasil penelitian menunjukkan bahwa efektivitas output PKH bidang kesejahteraan sosial yang dapat dilihat dari dua indikator telah tercapai. Hasil penelitian menunjukkan bahwa KPM telah mendapatkan makanan bergizi secara rutin 1 (satu) minggu 1 (satu) kali dengan persentase ketercapaian 84\% dari 80\% target yang diharapkan. Demikian juga dengan kriteria KPM mendapatkan perawatan kesehatan secara rutin yaitu 1 (satu) tahun 1 (satu) kali dengan persentase ketercapaian 84\% dari 80\% target yang diharapkan.

\section{Pembahas an}

Efektivitas PKH di Desa Sumber Kejayan pada indikator input telah efektif, karena KPM telah tepat sasaran berdasarkan kriteria yang ditentukan Kementerian Sosial. Kriteria indikator input yang digunakan dalam penelitian ini sama dengan kriteria penelitian yang dilakukan oleh Rohmi (2018:64) yang terdiri dari status kepemilikan bangunan tempat tinggal, status lahan tempat tinggal yang ditempati, jenis lantai terluas, jenis dinding terluas, kondisi dinding, jenis atap terluas, kondisi atap, sumber air minum, cara membeli air minum, sumber penerangan, daya penerangan, bahan bakar utama untuk memasak dan kepemilikan fasilitas BAB serta jenis kloset yang digunakan. Hal serupa juga dikatakan oleh Sjafari (2014: 49) bahwa fasilitas rumah yang digunakan sebagai kriteria kesejahteraan masyarakat adalah luas lantai rumah, sumber air minum, fasilitas tempat buang air besar rumah tangga dan juga tempat penampungan kotoran akhir.

Kemudian pada indikator proses juga telah efektif, dimana persentase yang diperoleh berada pada kategori sangat efektif menurut acuan efektivitas Litbang Depdagri Tahun 1991. Efektivitas proses ditentukan oleh kemampuan organisasi untuk memanfaatkan sumber daya yang dimiliki, manajemen dan penggunaan teknologi agar dapat menghasilkan nilai (Jones, 1993:349). Salah satu sumber daya yang digunakan dalam mencapai output PKH adalah pendamping PKH yang memiliki kewajiban untuk melakukan pendampingan dalam mekanisme atau proses $\mathrm{PKH}$.

Indikator terakhir pada efektivitas PKH adalah output yang menunjukkan bahwa output PKH telah tercapai pada kategori pendidikan, kesejahteraan sosial, namun tidak tercapai pada 
beberapa kriteria kategori kesehatan. Berdasarkan tabel efektivitas output dalam bidang pendidikan dapat disimpulkan, bahwa indikator yang telah ditetapkan oleh Kementerian Sosial yang terdiri dari 2 (dua) kriteria telah tercapai, sehingga efektivitas PKH dalam bidang pendidikan telah efektif dalam pelaksanaannya.

Menurut Rohmi (2018:108) kesehatan adalah penting bagi anak-anak, termasuk pemberian vaksin, suplemen vitamin $\mathrm{A}$, pemantauan pertumbuhan, pemberian makan bayi, pemberantasan penyakit cacingan, dan manajemen terpadu untuk penyakit anak-anak. Angka kematian bayi dan angka harapan hidup dapat dilihat dari efektivitas masyarakat berobat ke berbagai sarana dan prasarana kesehatan yang ada maupun efektivitas pelayanan medis terhadap ibu hamil dan keluarga yang sakit (Sjafari, 2014:49). Layanan kesehatan merupakan kunci untuk kelangsungan KPM untuk sejahtera. Menurut Indrayani (2014:1) program keluarga harapan adalah suatu program yang sangat efektif untuk membantu Rumah Tangga Sangat Miskin (RTSM) dalam bidang pendidikan dan kesehatan.

Selain pada bidang pendidikan dan kesehatan, PKH juga diperuntukkan bagi KPM pada bidang kesejahteraan sosial. Kriteria pada output PKH kategori kesejahteraan sosial terdiri dari KPM usia lanjut yang harus mendapatkan makanan yang bergizi dengan memanfaatkan bahan pangan lokal dan memeriksakan kesehatan secara rutin minimal 1 (satu) kali dalam 1 (satu) tahun. Persentase hasil penelitian lebih besar daripada target yang diharapkan. Persentase ini menunjukkan bahwa pada output PKH pada bidang kesejahteraan telah tercapai. Menurut Indrayani (2014:4) efektivitas sebuah program dapat diukur dengan melihat tercapainya tujuan program. Tujuan yang hendak dicapai dalam PKH adalah KPM melaksanakan kewajiban di bidang pendidikan, kesehatan dan kesejahteraan sosial. Kriteria yang ada pada kategori kesejahteraan sesuai dengan tujuan PKH yaitu meningkatkan kualitas kesehatan pada KPM usia lanjut.

\section{PENUTUP}

PKH telah efektif dari aspek input dan proses, artinya KPM telah tepat sasaran dan proses PKH juga telah sesuai dengan ketentuan Kementerian Sosial, sedangkan PKH belum efektif dari aspek output bidang kesehatan. Hal itu dikarenakan dari 8 (delapan) kriteria terdapat 2 (dua) kriteria responden yang memiliki anak usia 0-11 bulan yang tidak sesuai dengan persentase yang diharapkan. Kriteria tersebut adalah frekuensi Ibu yang kurang dalam memeriksakan kesehatan ke fasilitas kesehatan pada masa nifas dan kriteria tentang frekuensi yang kurang pada pemeriksaan kesehatan bayi 0-1 bulan di fasilitas kesehatan. Kemudian indikator output PKH yang belum efektif juga terdapat pada pola makan anak usia 1-5 tahun dalam kesehariannya.

Berbeda halnya pada aspek output bidang kesehatan, PKH telah efektif dari aspek output bidang pendidikan. Hal tersebut dapat dilihat dari kategori Keluarga Penerima Manfaat KPM yang memiliki anak usia sekolah pada jenjang SD/SMP/SMA/Sederajat. KPM telah melaksanakan kewajiban untuk mendaftarkan anak usia sekolah di satuan pendidikan dan telah memenuhi kehadiran $85 \%$ setiap bulan. Oleh karena itu, dapat disimpulkan output PKH di bidang pendidikan telah tercapai. Kemudian untuk output PKH kategori kesejahteraan sosial juga telah efektif, KPM usia lanjut telah mendapatkan makanan sehat dan perawatan dari keluarga secara rutin.

\section{DAFTAR PUSTAKA}

Badan Pusat Statistik. 2018. Persentase Penduduk Miskin Maret 2018 Turun menjadi 9,82\%. https://www.bps.go.id/website/images/Kemiskinan-Maret-2018-ind.jpg. (diakses pada $13 / 02 / 2019)$.

Budiani, N. W. 2007. Efektivitas Program Penanggulangan Pengangguran Karang Taruna "Eka Taruna Bhakti" Desa Sumerta Kelod Kecamatan Denpasar Timur Kota Denpasar. Jurnal Ekonomi dan Sosial. 2(1): 49-57.

Indrayani, F. K. 2014. Efektivitas Program Keluarga Harapan di Desa Sugihwaras Kecamatan Saradan Kabupaten Madiun. Publika.2(3): 1-11. 
Jones, Gareth R. 1993. Organizational Theory: Text and Cases. New York: Wesley Publishing Company.

Kelompok Kerja Pengelola Data Terpadu Program Penanganan Fakir Miskin. 2016. Pedoman Umum Mekanisme Pemutakhiran Mandiri Data Terpadu Program Penanganan Fakir Miskin. Jakarta: Sekretaris Eksekutif Tim Nasional Percepatan Penanggulangan Kemiskinan (TNP2K).

Neolaka, A. 2016. Metode Penelitian Kuantitatif dan Statistik. Bandung: Rosdakarya.

Rohmi, M. L. 2018. Efektivitas Kebijakan Penanggulangan Kemiskinan Berbasis Bantuan Dan Perlindungan Sosial Bagi Masyarakat (Studi Kasus Di Kabupaten Pringsewu Provinsi Lampung). Tidak Dipublikasikan. Tesis. Universitas Lampung: Magister Ilmu Ekonomi.

Sjafari, A. 2014. Kemiskinan dan Pemberdayaan Kelompok. Yogyakarta: Fisip Untirta Press. 